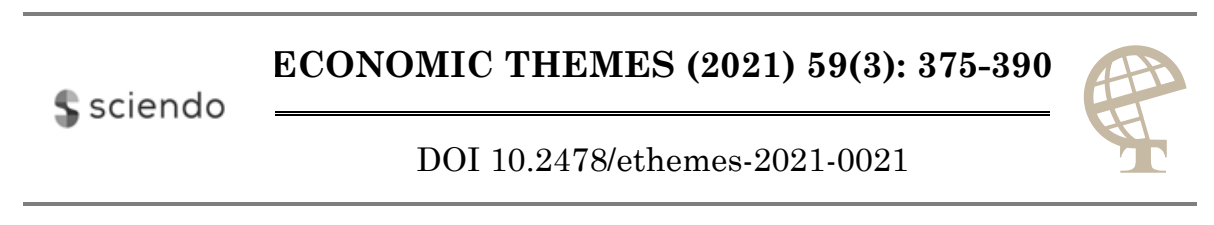

\title{
PANEL COINTEGRATION ANALYSIS OF MILITARY EXPENDITURE AND ECONOMIC GROWTH IN THE SELECTED BALKAN COUNTRIES
}

\author{
Branimir Kalaš \\ University of Novi Sad, Faculty of Economics in Subotica, Serbia \\ $\triangle$ branimir.kalas@ef.uns.ac.rs \\ Vera Mirović \\ University of Novi Sad, Faculty of Economics in Subotica, Serbia \\ $\square$ vera.mirovic@ef.uns.ac.rs \\ Nada Milenković \\ University of Novi Sad, Faculty of Economics in Subotica, Serbia \\ $\bowtie$ nada.milenkovic@ef.uns.ac.rs
}

UDC

330.341:355

Original

scientific paper

Received: 04.09.2020

Accepted:

02.07.2021
Abstract: The issue of security and safety i s a fundamental condition for stable economic trends. Military expenditure can be a very powerful tool for a rapid economic growth. The paper examines the long-run relationship between military expenditure and economic growth in the selected Balkan countries, such as Albania, Bosnia and Herzegovina, Croatia, Montenegro, North Macedonia, Serbia and Slovenia for the period 2004-2018. The analysis implies a panel unit root test, a panel cointegration test, as well as a panel Granger causality test. The results have identified a long-run relationship between military expenditure and economic growth in the Balkan countries based on panel data analysis. Also, empirical findings have confirmed that shock experience in one of the countries' military expenditure and economic growth have effect on other countries. Finally, the results have determined unidirectional causality from military expenditure to economic growth in these countries and not vice versa.

Keywords: military expenditure, economic growth, Balkan countries, panel cointegration analysis

JEL classification: C23, C51, H2, O11, O23 


\section{Introduction}

Economic growth and security represent two pressing issues for many developing countries (Azam and Feng, 2015), as well as for the less developed ones. Petrov and Trivić (2018) indicate that the standard way to estimate economic success is by measuring economic growth. Loganathan et al. (2018) emphasized that country needs a remarkable fiscal policy to overcome unstable economic scenario and sustain development. Barros (2002) emphasize that the Balkans is the most religiously and ethnically non-homogenous region in which ethnic conflicts and wars have often dominated the region's agenda. Malizard (2016) argues that military expenditure are related to security needs and budgetary limits. It implies that an increase in perceived threats should lead to a rise in military expenditure whereas unfavorable economic situations could have negative impact on military outlays. Daddi et al. (2016) determined military sector as a sector that enables a variety of public infrastructures as a communication and transportation networks. Utrero-González et al. (2017) highlight that military spending is necessary for providing security. Military expenditure represents a country's outlays in order to buy the equipments used for the production of military potency and capacity (Kollias and Paleologou, 2019).

Analyzing database of 109 non-high-income economies for the period 19982014, D'Aggostino et al. (2019) found that military expenditure is an essential weapon for economic growth. Acikgoz and Cinar (2017) notice that some of the economists argue that higher expenditures damage economic growth by transferring resources from more productive sectors to government that uses them less efficiently.

This research contributes to the empirical literature in a number of important ways. First, we examine the nexus between military expenditure and economic growth in the selected Balkan countries, where, to our knowledge, this is the first research that estimates these components in the economies of Albania, Bosnia and Herzegovina, Croatia, Montenegro, North Macedonia, Serbia and Slovenia. Second, this research is necessary to identify the economic effects of military expenditure in these countries, because today we can notice that the Balkan countries are increasingly investing in the military sector. The need for this research is manifested in providing information support and guidance to governments in the Balkan countries about the relationship between military expenditure and economic growth. This region is often a confidential area where conflicts were presented. The structure of this research is as follows: after the introduction, there is a theoretical background presented about the nexus between military expenditure and economic growth in the world, where the previous empirical studies examined their relationship. The largest segment of this research covers empirical analysis which consist of descriptive statistics, panel unit root tests, as well as panel cointegration analysis of military expenditure and economic 
growth in the selected Balkan countries: Albania, Bosnia and Herzegovina, Croatia, Montenegro, North Macedonia, Serbia and Slovenia. The last segment includes summarizes and conclusion about cointegration between these components in THE observed countries for the period 2004-2018.

\section{Literature review}

The effect of military expenditure on the economic growth is a controversial area of research among economists, and there is no uniform conclusion about their effect on the economy (Alptekin and Levine, 2012). The discussion in the empirical papers on the economic impact of military spending started with the Benoit (1978). There are many papers which have examined nexus between military expenditure and economic growth in the world (Dune and Uye, 2008; Malizard, 2010; Alptekin and Levine, 2012; Hou and Chen, 2013; Tiwari and Shahbaz, 2013; Furuoka et al. 2014; Dimitraki and Menla-Ali, 2015; Compton and Paterson, 2015; Pan et al. 2015; Manamperi, 2016; Cevik and Ricco, 2017; Phiri, 2017; Markowski et al. 2017; Smith, 2017; Emmanouilidis and Karpetis, 2018; Biscione and Caruso, 2019; Dimitraki and Win, 2020).

Dunne and Uye (2008) analyzed 102 empirical papers that have evaluated the nexus between military expenditure and economic growth and their findings confirmed that a positive relationship is identified in $19 \%$ of the observed studies. Furthermore, a negative relationship is determined in $39 \%$, while $42 \%$ of the studies found an unclear nexus between military expenditure and economic growth. Malizard (2010) investigated a causal relationship between military expenditure and economic growth in France for the period 1960-2008 and the empirical results showed bidirectional causality between the observed variables. Farzanegan (2012) analyzed military expenditure and economic growth in Iran for the period 19592007 and his research found a positive and significant relationship between these variables. The results of Granger causality test reflect that there is a unidirectional causality from military expenditure to economic growth in Iran.

The empirical study of Dune and Tian (2013) identified a negative effect of military expenditure on economic growth. Tiwari and Shahbaz (2013) estimated the impact of defence spending on economic growth in India for the period 19712010 and their findings manifested bidirectional causal relationship between these variables in India. Hou and Chen (2013) researched the impact of military expenditure on economic growth in thirty-five developing economies from 1975 to 2019. By using GMM system estimators, their findings indicated a negative and significant impact on economic growth in the observed countries. Furuoka et al. (2014) estimated the nexus between military expenditure and economic growth in China for the period 1989-2011. Their findings showed that there was a long-run nexus between military expenditure and economic growth. 
Likewise, Granger causality test reflected a unidirectional causality from economic growth to military expenditure. Yildrim and Öcal (2014) investigated the effect of military expenditure on economic growth for 128 countries from 2000 to 2010, where their findings showed that military expenditure had a positive and significant effect on economic growth. Dimitraki and Menla-Ali (2015) revealed positive nexus between military expenditure and economic growth in China from 1950 to 2011. Pan et al. (2015) investigated the relationship between per capita military spending and economic growth in 10 Middle Eastern countries for the period 1988-2010. The results of their study showed that there was a causality running from per capita military spending to economic growth only in Turkey and Israel. Also, there was an unidirectional causality running from economic growth to military spending for Egypt, Kuwait, Lebanon, Israel and Syria for the observed period. Manamperi (2016) confirmed significant and negative impact on economic growth for Turkey. On the other hand, this research showed that there was no significant effect of military expenditure on economic growth in Greece. Nikolaidou (2016) determined no significant effect of military expenditure on economic growth in Greece, Portugal and Spain from 1960 to 2014.

Churchill and Yew (2017) examined the relationship between military expenditure and economic growth and their study found that growth-retarding effects of military expenditure was more pronounced in less developed countries. Kollias et al. (2017) analyzed military expenditure and economic growth in thirteen Latin American economies from 1961 to 2014. Their findings showed that empirical results were not uniformed for the observed countries which implied that unidirectional, bidirectional, as well as non-causality between variables were established. Phiri (2017) analyzed the nexus between military spending and economic growth in South Africa from 1988 to 2015. Empirical findings identified a non-linear relationship between these variables and suggested that the current level of military spending was too high in South Africa at the time. He suggested that military expenditure need to be transferred towards more productive expenditure that had not military character in order to improve economic growth.

Yolcu Karadam et al. (2017) examined the effect of military expenditure on economic growth in Middle East countries and Turkey for the period 1988-2012 and their results showed that the impact of military expenditure on economic growth was nonlinear. The empirical study of Emmanoulidis and Karpetis (2018) analyzed nexus between military expenditure and economic growth in the United States economy for the period 1961-2016. Their findings showed a short-run relation running from military expenditure to economic growth. Dunne and Smith (2019) noticed that relationship between the output and military expenditure was likely to be negative if the system was affected by strategic shocks. On the other hand, if the system was driven by economic shocks, the observed correlation would have a positive character. 
Biscione and Caruso (2019) analyzed military expenditure in transition countries over the period 1990-2015 and highlighted that military expenditure could have a detrimental effect on the national economy. Khalid and Habimana (2019) analyzed military spending and economic growth in Turkey for the period 1961-2014. Their results showed that military spending had a significant negative impact on GDPpc growth at business cycles of 16 years and longer. Also, causality test reflects that growth responded to changes in military spending at business cycles of 8 years and above. Saba and Ngepah (2019) investigated the relationship between military expenditure and economic growth in 35 African countries for the period 1990-2015. Their results of GMM showed that military expenditure had a negative impact on economic growth in Africa. D'Agostino et al. (2020) examined the impact of military spending on economic growth for 63 economies from 1980 to 2014. The findings revealed that military spending had a negative and significant effect in the long-run. Dimitraki and Win (2020) analyzed the causality between military expenditure and economic growth in Jordan for the period 1970-2015. The results of their empirical studies confirmed a positive short-run, as well as, a longrun relationship between these variables in Jordan for the observed period.

\section{Materials and methods}

To undertake the empirical analysis, the present research used recent data available for seven Balkan countries: Albania, Bosnia and Herzegovina, Croatia, Montenegro, North Macedonia, Serbia and Slovenia for the period 2004-2018. The empirical analysis measures military expenditure as a percentage share in gross domestic product and economic growth measured by gross domestic product rate. The data is obtained from World Bank and International Monetary Fund and implies data series for the period 2004-2018.

The panel unit root test is one of the most essential tests in econometric procedure in order to determine the integration of each variable. This analysis includes LLC test that supposes that there is a regular unit root process across the cross-sections. Panel unit root tests such as IPS, ADF and PP test assume that there are individual unit root processes across the cross-sections (Adhikari, Chen, 2012). The panel cointergation test is often used to identify the existence of the long-run equilibrium relationship between two or more variables. The long-run causality mplies that the variables move together over time. If the series had a panel unit root, then we apply panel cointegration analysis. The panel cointegration test enables for cross-sectional interdependence with both different individual effects and deterministic trends to be determined as:

$$
\begin{aligned}
\ln Y i t & =\alpha_{i t}+\delta_{i t}+\beta_{i} \ln E_{i t} \varepsilon_{i t} \\
\varepsilon_{i t} & =\rho_{i t} \varepsilon_{i t}-1+u_{i t}
\end{aligned}
$$


where $\mathrm{i}=1, \ldots \ldots \mathrm{N}$ reflects the panel member, $\mathrm{t}=1, \ldots \ldots \mathrm{T}$ refers to the time period, $Y$ reflects the GDP, TET reflects the total environmental taxes and $\beta$ i reflects the slope coefficient. The parameters $\alpha i t$ and $\delta i$ let for possibility of country-specific effects and deterministic trend effects, where cit manifests the evaluated residual deviations from the long-run nexus (Adhikari, Chen, 2012).

The present research uses Granger causality test to identify the direction of the causality nexus between military expenditure and economic growth. These variables for the selected Balkan countries were used in Granger causality test: LGDPrate as logarithm value of gross domestic product growth rate and LME as logarithm value of military expenditure.

$$
\begin{aligned}
& y_{t}=-\sum_{j=1}^{m} a_{11, j} y_{t-j}-\sum_{j=1}^{m} a_{12, j} x_{t-j}+u_{t 1} \\
& x_{t}=-\sum_{j=1}^{m} a_{21, j} y_{t-j}-\sum_{j=1}^{m} a_{22, j} x_{t-j}+u_{t 2}
\end{aligned}
$$

Granger causality implies that, if for each unit we are able to estimate y by using all available data other than those data used in estimating $\mathrm{x}$, we say that $\mathrm{x}$ is causing y. By adjusting the data of deterministic elements, such as trend and seasonal mobility, it is required to understand that such conversions cannot be detrimental to the causality structure for taking the logarithms, as well as the differences of the first degree in order to enable for the covariance stationary (Yilgör et al. 2012).

\section{Empirical results}

This part includes the analysis trend of gross domestic product rate and military expenditure in the selected Balkan countries (Albania, Bosnia and Herzegovina, Croatia, Montenegro, North Macedonia, Serbia and Slovenia) for the period 2004 to 2018. After that, the empirical study implies the panel unit root tests, as well as the panel cointegration tests and Granger causality test between the military expenditure and economic growth. 
Figure 1. GDP rate and military expenditure in the Balkan countries

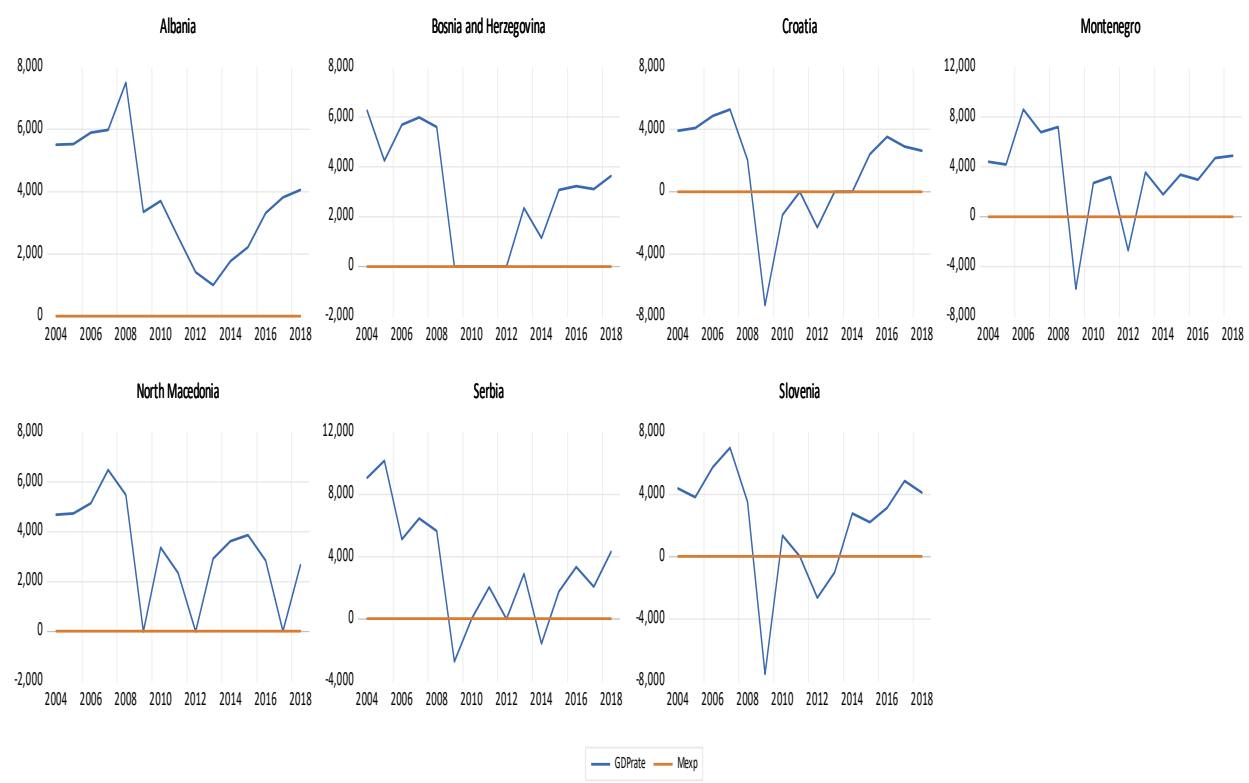

Source: Authors' calculation

Figure 1 presents GDP rate and military expenditure trends in the Balkan countries for the period 2004-2018. It can be seen that the selected countries had stable and higher growth until 2009, when the financial crisis escalated and also caused the slowdown of these economies. Domazet et al. (2018) notice that ten years after the outbreak of the world economic crisis, the effects are still noticeable here. For example, Slovenia recorded the highest negative GDP rate of $7.36 \%$, Montenegro $-5.8 \%$, Serbia $-2.72 \%$, Bosnia and Herzegovina $-0.82 \%$, North Macedonia $-0.36 \%$. On the other side, Albania also had smaller GDP rate, but still positive growth of $3.37 \%$ in 2009 . The maximum GDP rate is identified in Serbia in 2005 when GDP rate was $10.15 \%$. On the contrary, the smallest GDP rate is determined in Slovenia in 2009 when GDP rate was $-7.54 \%$. In the last year, Albania, Montenegro, Serbia and Slovenia had GDP rate above 4\%, while other countries had growth around $2-3 \%$ which is an encouraging fact for the economic development in this region. Analyzing the military expenditure share in GDP, we can see that their share is decreased in GDP in all countries from 2004 to 2018. For example, the percentage share of military expenditure declined above 1\% GDP in Montenegro, North Macedonia and Serbia. Likewise, the percentage share of military expenditure in Bosnia and Herzegovina decreased by 0.08 for the observed period, which is similar to trends in Albania and Croatia. 
Table 1. Descriptive statistics

\begin{tabular}{|l|c|c|c|c||}
\hline \hline Country & Mean & Std. Dev. & Max & Min \\
\hline \multicolumn{7}{|c|}{ GDP rate } \\
\hline Albania & 3.84 & 1.91 & 7.5 & 1.01 \\
\hline Bosnia and Herzegovina & 2.96 & 2.34 & 6.25 & -0.82 \\
\hline Croatia & 1.31 & 3.35 & 5.28 & -7.29 \\
\hline Montenegro & 3.32 & 3.63 & 8.6 & -5.8 \\
\hline North Macedonia & 3.17 & 2.08 & 6.47 & -0.46 \\
\hline Serbia & 3.23 & 3.66 & 10.15 & -2.73 \\
\hline Slovenia & 2.16 & 3.65 & 6.98 & -7.54 \\
\hline & 1.43 & 0.25 & 1.98 & 1.1 \\
\hline Albania & 1.17 & 0.18 & 1.54 & 0.91 \\
\hline Bosnia and Herzegovina & 1.64 & 0.15 & 1.84 & 1.36 \\
\hline Croatia & 1.81 & 0.44 & 2.72 & 1.36 \\
\hline Montenegro & 1.44 & 0.46 & 2.38 & 0.94 \\
\hline North Macedonia & 2.19 & 0.28 & 2.97 & 1.85 \\
\hline Serbia & 1.26 & 0.25 & 1.61 & 0.93 \\
\hline Slovenia & & & & \\
\hline \hline
\end{tabular}

Source: Authors' calculation

Table 1 shows a descriptive statistics of GDP rate and military expenditure in the Balkan countries (Albania, Bosnia and Herzegovina, Croatia, Montenegro, North Macedonia, Serbia and Slovenia) for the period 2004-2018. The average GDP rate was $2.85 \%$, where Albania had the highest average GDP rate of $3.84 \%$ during observed period. Similarly, Montenegro, North Macedonia and Serbia had GDP rate above $3 \%$, while Bosnia and Herzegovina had GDP rate of $2.96 \%$. On the other hand, Croatia had the smallest GDP rate of $1.31 \%$ which is far less than other analyzed countries. It can be seen that only Croatia and Slovenia had mean GDP growth rate below the average level for the observed period. Looking at the military expenditure, the average share is $1.56 \%$ of GDP in the Balkan countries, where Serbia had the highest share of $2.19 \%$ of GDP. As one can notice, other countries had mean percentage share below 2\% of GDP, where Bosnia and Herzegovina had the smallest share of military expenditure (1.17\% of GDP). 
Table 2. Panel unit root tests

\begin{tabular}{||c|c|c|c||}
\hline \multicolumn{4}{|c||}{$\mathrm{H}_{0}$ : Panels containing unit roots } \\
\hline $\begin{array}{c}\text { Panel unit root } \\
\text { tests }\end{array}$ & $\mathrm{H}_{\mathrm{a}}$ : Panels are stationary \\
\hline \multicolumn{5}{|c||}{ Cross-sections } & $\Delta$ GDP rate & $\Delta$ ME \\
\hline LLC & 7 & $-10.65^{* * *}$ & $-8.86^{* * *}$ \\
\hline IPS & 7 & $-7.78^{* * *}$ & $-6.43^{* * *}$ \\
\hline ADF & 7 & $73.49^{* * *}$ & $60.83^{* * *}$ \\
\hline PP & 7 & $107.36^{* * *}$ & $72.76^{* * *}$ \\
\hline I & 7 & $-8.08^{* * *}$ & $-7.22^{* * *}$ \\
\hline LLC & 7 & $-5.16^{* * *}$ & $-4.81^{* * *}$ \\
\hline IPS & 7 & $50.10^{* * *}$ & $45.71^{* * *}$ \\
\hline ADF & 7 & $102.49^{* * *}$ & $71.94^{* * *}$ \\
\hline PP & Intercept and trend & \\
\hline
\end{tabular}

Source: Authors' calculation

The results of these tests show that the selected variables are stationary at the first difference. It means that null hypothesis can be rejected at the $1 \%$ level of significance when applying each variable at the first difference and we can confirm that these variables are integrated of order one process or I (1).

Table 3. Cross sectional dependence tests

\begin{tabular}{||l|c|c||}
\hline Variable & GDP rate & ME \\
\hline Breusch-Pagan LM & $171.34 * * *$ & $156.33^{* * *}$ \\
\hline Pesaran scaled LM & $23.19 * * *$ & $20.88^{* * *}$ \\
\hline Bias-corrected scaled LM & $22.94 * * *$ & $20.63 * * *$ \\
\hline Pesaran CD & $12.95 * * *$ & $12.21 * * *$ \\
\hline
\end{tabular}

Source: Authors' calculation

The results based on Table 3 show the existence of cross-sectional dependence in the series and cointegration equation which implies that shock experience in one of the countries' military expenditure and economic growth has an effect on other countries. GDP rate and ME are highly statistically significant for these tests given in Table 3 and it means that there is horizontal cross-section relationship concerning these variables. 
Table 4. Pedroni cointegration test

\begin{tabular}{|c|c|c|c|c|}
\hline \multirow[b]{2}{*}{ Cointegration } & \multicolumn{2}{|c|}{ GDPrate - ME } & \multicolumn{2}{|c|}{ ME - GDPrate } \\
\hline & Intercept & $\begin{array}{c}\text { Intercept \& } \\
\text { trend }\end{array}$ & Intercept & $\begin{array}{c}\text { Intercept \& } \\
\text { trend }\end{array}$ \\
\hline \multicolumn{5}{|c|}{ Within-Dimension } \\
\hline Panel v-statistic & -1.37 & -3.43 & -0.06 & -1.99 \\
\hline Panel rho-statistic & $-4.63 * * *$ & $-1.82 * *$ & $-3.04 * * *$ & $-1.67 *$ \\
\hline Panel PP-statistic & $-12.98 * * *$ & $-26.48 * *$ & $-5.32 * * *$ & $-6.61 * * *$ \\
\hline $\begin{array}{l}\text { Panel ADF- } \\
\text { statistic }\end{array}$ & $-6.49 * * *$ & $-8.66 * *$ & $-3.67 * * *$ & $-4.58 * * *$ \\
\hline \multicolumn{5}{|c|}{ Between-Dimension } \\
\hline Group rho-statistic & $-2.33 * * *$ & -0.16 & $-1.58 * * *$ & -0.18 \\
\hline Group PP-statistic & $-12.55 * *$ & $-23.03 * * *$ & $-8.13 * * *$ & $-8.52 * * *$ \\
\hline $\begin{array}{l}\text { Group ADF- } \\
\text { statistic }\end{array}$ & $-5.02 * * *$ & $-6.84 * * *$ & $-5.05 * * *$ & $-5.19 * * *$ \\
\hline
\end{tabular}

Source: Authors' calculation

Table 4 shows that Panel rho, Panel PP and Panel ADF are statistically significant at 5\%, while Panel V is found not to be significant. From the aspect of the group statistics, Group PP and Group ADF are statistically significant at $1 \%$. Empirical findings manifests that there is a long-term nexus between military expenses and economic growth in the observed countries.

Table 5. Unrestricted Cointegration Rank Test (Trace and Maximum Eigenvalue)

\begin{tabular}{|l|c|c|c|c||}
\hline \hline Hypothesized & \multicolumn{2}{|c|}{ Fisher stat.* } & \multicolumn{2}{c|}{ Fisher stat.* } \\
\hline No. of CE (s) & $\begin{array}{c}\text { From Trace } \\
\text { test }\end{array}$ & Prob. & $\begin{array}{c}\text { From Max- } \\
\text { Eigen test }\end{array}$ & Prob. \\
\hline None & 84.91 & 0.0000 & 63.28 & 0.0000 \\
\hline At most 1 & 55.11 & 0.0000 & 55.11 & 0.0000 \\
\hline
\end{tabular}

Source: Authors' calculation

The results of the Fisher cointegration test are given in Table 5 and it can be noticed that there is long-run nexus between military expenditure and economic growth in the Balkan countries, where variables are specified by the cointegration vector 1 . 
Table 6. Individual cross-section results

\begin{tabular}{|c|c|c|c|c|}
\hline Cross-Section & $\begin{array}{c}\text { Trace Test } \\
\text { Statistics }\end{array}$ & Prob. & $\begin{array}{c}\text { Max-Eigen } \\
\text { Test Statistics }\end{array}$ & Prob. \\
\hline \multicolumn{5}{|c|}{ Hypothesis of no cointegration } \\
\hline Albania & 27.97 & 0.0004 & 24.70 & 0.0008 \\
\hline Bosnia and Herzegovina & 13.34 & 0.1029 & 10.86 & 0.1614 \\
\hline Croatia & 18.23 & 0.0189 & 11.39 & 0.1357 \\
\hline Montenegro & 25.46 & 0.0012 & 20.57 & 0.0044 \\
\hline North Macedonia & 26.18 & 0.0009 & 17.25 & 0.0163 \\
\hline Serbia & 37.28 & 0.0000 & 29.66 & 0.0001 \\
\hline Slovenia & 15.72 & 0.0462 & 11.23 & 0.1432 \\
\hline \multicolumn{5}{|c|}{ Hypothesis of at most 1 cointegration relationship } \\
\hline Albania & 3.27 & 0.0704 & 3.27 & 0.0704 \\
\hline Bosnia and Herzegovina & 2.48 & 0.1152 & 2.48 & 0.1152 \\
\hline Croatia & 6.83 & 0.0089 & 6.83 & 0.0089 \\
\hline Montenegro & 4.89 & 0.0271 & 4.89 & 0.0271 \\
\hline North Macedonia & 8.92 & 0.0028 & 8.92 & 0.0028 \\
\hline Serbia & 7.62 & 0.0058 & 7.62 & 0.0058 \\
\hline Slovenia & 4.49 & 0.0340 & 4.49 & 0.0340 \\
\hline
\end{tabular}

Source: Authors' calculation

After presenting the results of the panel cointegration tests, Table 6 shows the potential long-run nexus between military expenditure and economic growth by the analyzed countries. It can see that there is a long-run relationship between these variables in Albania, Montenegro, North Macedonia and Serbia at 5\% significance level.

Table. 7. Panel Granger causality test

\begin{tabular}{||l|l|c||}
\hline Direction & F-stat. & Prob. \\
\hline LGDPrate $\rightarrow$ LME & 0.6294 & 0.5290 \\
\hline LME $\rightarrow$ LGDPrate & 2.2633 & 0.0236 \\
\hline
\end{tabular}

Source: Authors' calculation

Table 7 shows the causality between military expenditure and economic growth in the Balkan countries from 2004-2018. The empirical results show an unidirectional causal relation running from military expenditure to economic 
growth at 5\% significance level. It implies that when the military expenditure as a percentage share in GDP increases in the Balkan countries, the economic growth of these countries will increase.

\section{Conclusion}

Although there is a number of empirical papers on the nexus between military expenditure and economic growth in the world, no studies have analyzed yet the Balkans and the countries that have been members of the Socialist Federal Republic of Yugoslavia in terms of this relationship. This research has estimated the relationship between military expenditure and economic growth in the selected Balkan countries of Albania, Bosnia and Herzegovina, Croatia, Montenegro, North Macedonia, Serbia and Slovenia for the period 2004-2018. The aim of this research is to evaluate the long-run nexus between selected variables based on the panel data analysis. The analysis covers the panel unit root test, the panel cointegration test, as well as, the panel causality between the military expenditure and economic growth in the observed states. The results reveal a long-run cointegrated relationship between the military expenditure and economic growth in the selected countries. Likewise, there is a significant relation running from military expenditure to economic growth, measured by gross domestic product rate. The empirical results have shown that there is a long-run nexus between the military expenditure and economic growth in Albania, Montenegro, North Macedonia and Serbia at 5\% significance level. On the other hand, there is no long-run relationship between these variables in Bosnia and Herzegovina and Slovenia. Finally, the results of causality test show that there is an unidirectional causal relation running from military expenditure to economic growth and not vice versa. The study has provided better understanding of the relationship between military the expenditure and economic growth in the selected countries and has given a certain guidance to policy makers in these countries about the importance of military expenditure for economic growth.

\section{References}

Acikgoz, B. \& Cinar, S. (2017). Public Spending and Economic Growth: An Empirical Analysis of Developed Countries. Ekonomicky časopis, 65(5), 448-458.

Adhikari, D. \& Chen, Y. (2012). Energy Consumption and Economic Growth: A Panel Cointegration Analysis for Developing Countries. Review of Economics \& Finance, $3,68-80$.

Alpteki, A. \& Levine, P. (2012). Military Expenditure and Economic Growth: A MetaAnalysis. European Journal of Political Economy, 28, 636-650. doi: 10.1016/j.ejpoleco.2012.07.02. 
Azam, M. \& Feng, Y. (2015). Does military expenditure increase external debt? Evidence from Asia. Defence and Peace Economics, 28(5), 550-567. doi: 10.1080/10242694.2015.1072371.

Barros, C. (2002). Development and conflict in the Balkans: Catch-up and military expenditure. Defence and Peace Economics, 13(5), 353-363. doi: $10.1080 / 10242690213510$.

Benoit, E. (1978). Growth and Defence in LDCs. Economic Development and Cultural Change, 26: 271-280.

Biscione, A. \& Caruso, R. (2019). Military Expenditures and Income Inequality Evidence form a Panel of Transition Countries (1990-2015). Defence and Peace Economics: 1-22. doi: 10.1080/10242694.2019.1661218.

Cevik, S. \& Ricco, S. (2017). No Buck for the Bang: Revisiting the Military-Growth Nexus. Empirica 45, 639-653. doi: 10.1007/s10663-017-9380-8.

Churchill, S. \& Yew, S.Y. (2017). The Effect of Military Expenditure on Growth: An Empirical Synthesis. Empirical Economics, 55, 1357-1387. doi: 10.1007/s00181-0171300-z.

Compton, R. \& Paterson, B. (2015). Military Spending and Growth: The Role of Institutions. Defence and Peace Economics, 27(3), 301-322. doi: 10.1080/10242694.2015.1060022.

Daddi, P., D'Agostino, G. \& Pieroni, L. (2016): Does military spending stimulate growth? An empirical investigation in Italy. Defence and Peace Economics, 29(4), 440-458. doi: 10.1080/10242694.2016.1158438.

D’Agostino, G., Dune, J.P. \& Pieroni, L. (2017). Military Expenditure, Endogeneity and Economic Growth. Defence and Peace Economics, 30(5), 1-16. doi: 1080/10242694.2017.1422314.

D’Agostino, G., Dunne, J.P., Lorusso, M. \& Pieroni, L. (2020). Military Spending, Corruption, Persistence and Long Run Growth. Defence and Peace Economics, 1-11. doi: 10.1080/10242694.2020.1751503.

Dimitraki, O. \& Menla-Ali, F. (2015). The Long-Run Causal Relationship between Military Expenditure and Economic Growth in China: Revisited. Defence and Peace Economics, 26(3), 311-326. doi: 10.1080/10242694.2013.810024.

Dimitraki, O. \& Win, S. (2020). Military Expenditure Economic Growth Nexus in Jordan: An Application of ARDL Bound Test Analysis in the Presence of Breaks. Defence and Peace Economics, 1-18. doi: 10.1080/10242694.2020.173011.

Domazet, I., Zubović, J. \& Lazić, M. (2018). Driving Factors of Serbian Competitiveness Digital Economy and ICT. Strategic Management, 23(1), 20-28.

Dunne, J.P. \& Tian, N. (2013). Military Expenditure, Economic Growth and Heterogeneity. Defence and Peace Economics, 26(1), 15-31. doi: 10.1080/10242694.2013.848575.

Dunne, J.P. \& Smith, R.P. (2019). Military Expenditure, Investment and Growth. Defence and Peace Economics, 1-14. doi: 10.1080/10242694.2019.1636182.

Emmanoulidis, K. \& Karpetis, C. (2018). The Defense-Growth Nexus: A Review of Time Series Methods and Empirical Results. Defence and Peace Economics, 1-18. doi: 10.1080/10242694.2018.1428261.

Hou, N. \& Chen, B. (2013). Military expenditure and economic growth in developing countries: Evidence from system GMM estimates. Defence and Peace Economics, 24(3), 183-193. doi: 10.1080/10242694.2012.710813. 
Farzanegan, M.R. (2012). Military Spending and Economic Growth: The Case of Iran. Defence and Peace Economics, 25(3), 247-269. doi: 10.1080/10242694.2012.723160

Furuoka, F., Oishi, M. \& Karim, M. (2014). Military expenditure and economic development in China: an empirical inquiry. Defence and Peace Economics, 27(1), 137-160. doi: $10.1080 / 10242694.2014 .898383$.

Khalid, U. \& Habimana, O. (2019). Military Spending and Economic Growth in Turkey: A Wavelet Approach. Defence and Peace Economics, 1-15. doi: 10.1080/10242694.2019.1664865.

Kollias, C., Paleologou, S.M., Tzeremes, P. \& Tzeremes, N. (2017). Defence expenditure and economic growth in Latin American countries: evidence from linear and nonlinear causality tests. Latin American Economic Reviews, 26(2), 1-25. doi: 10.1007/s40503017-0039-4.

Kollias, C. \& Paleologou. S. (2019). Military Spending, Economic Growth and Investment: A Disaggregated Analysis by Income Group. Empirical Economics, 56(3), 935-958. doi: 10.1007/s00181-017-1379-2.

Loganathan, N., Ismail, S., Streimikiene, D., Hassan, A., Zavadskas, E. \& Mardini, A. (2018). Tax Reform, Inflation, Financial Development and Economic Growth in Malaysia. Romanian Journal of Economic Forecasting, 20(4), 152-165.

Malizard, J. (2010). Causality between Economic Growth and Military Expenditure: The Case of France. Defence \& Security Analysis, 26(4), 401-413. doi: $10.1080 / 14751798.2010 .534648$.

Malizard, J. (2016). Military Expenditure and Economic Growth in the European Union: Evidence from SIPRI's Extended Dataset. Economics of Peace and Security Journal, 11(2): 38-44.

Manamperi, N. (2016). Does Military Expenditure Hinder Economic Growth? Evidence from Greece and Turkey. Journal of Policy Modeling, 38(6), 1171-1193. doi: 10.1016/j.jpolmod.2016.04.003.

Markowski, S., Chand, S. \& Wylie, R. (2017). Economic Growth and Demand for Military Expenditure in the Indo-Pacific Asia Region. Defence and Peace Economics, 28(4), 473-490. doi: 10.1080/10242694.2016.1274059.

Nikolaidou, E. (2016). Greece, Portugal, Spain: New Evidence on the Economic Effects of Military Expenditure Using the New SIPRI Data. Economics of Peace and Security Journal, 11(2): 20-27.

Pan, C.I., Chang, T. \& Wolde-Rufael, Y. (2015). Military spending and economic growth in the Middle East countries: Bootstrap panel causality test. Defence and Peace Economics, 26(4), 443-456. doi: 10.1080/10242694.2014.891356.

Petrov, V. \& Trivić, N. (2018). The problem of defining and measuring sustainable income. The Annals of the Faculty of Economics in Subotica, 54(39), 19-31.

Pieroni, L. (2009). Military Expenditure and Economic Growth. Defence and Peace Economics, 20(4), 327-339. doi: 10.1080/10242690701589876.

Phiri, A. (2017). Does Military Spending Nonlinearly Affect Economic Growth in South Africa? Defence and Peace Economics, 1-14. doi: 10.1080/10242694.2017.1361272.

Saba, C.S. \& Ngepah, N. (2019). Military expenditure and economic growth: evidence from a heterogeneous panel of African countries. Economic Research - Ekonomska istraživanja, 32(1), 3586-3606. doi: 10.1080/1331677X.2019.1674179. 
Smith, R. (2017). Military Expenditure Data: Theoretical and Empirical Considerations. Defence and Peace Economics, 28(4), 422-428. doi: $10.1080 / 10242694.2016 .1245823$

Tiwari, A.K. \& Shahbaz, M. (2013). Does defence spending stimulate economic growth in India? A revisit. Defence and Peace Economics, 24(4), 371-395. doi: 10.1080/10242694.2012.710814.

Yildrim, J. \& Öcal, N. (2014). Military expenditures, economic growth and spatial spillovers. Defence and Peace Economics, 27(1), 87-104. doi: 10.1080/10242694.2014.960246.

Yilgör, M., Karagöl, E.T. \& Saygili, C.A. (2012). Panel Causality Analysis between Defence Expenditure and Economic Growth in Developed Countries. Defence and Peace Economics, 25(2), 193-203. doi:10.1080/10242694.2012.724879.

Yolcu Karadam, J., Yildrim, J. \& Öcal, N. (2017). Military expenditure and economic growth in Middle Eastern countries and Turkey: A non-linear panel data approach. Defence and Peace Economics, 28(6): 719-730. doi: 10.1080/10242694.2016.1195573

Utrero-González, N., Hromcová, J. \& Callado-Muñoz, F.J. (2017). Defence Spending, Institutional Environment and Economic Growth: Case of NATO. Defence and Peace Economics, 1-24. doi:10.1080/10242694.2017.1400292.

\section{PANEL KOINTEGRACIONA ANALIZA VOJNIH RASHODA I EKONOMSKOG RASTA U ODABRANIM ZEMLJAMA BALKANA}

Apstrakt: Pitanje bezbednosti i sigurnosti predstavlja fundamentalni uslov za stabilna ekonomska kretanja. Vojni rashodi mogu biti vrlo moćno sredstvo za brzi ekonomski rast. Ovaj rad ispituje dugoročnu vezu između vojnih rashoda i ekonomskog rasta u odabranim zemljama Balkana kao što su: Albanija, Bosna i Hercegovina, Hrvatska, Crna Gora, Severna Makedonija, Srbija i Slovenija za period 2004-2018. godine. Analiza uključuje panel testove jediničnog korena, panel kointegracioni test, kao i panel test kauzalnosti. Rezultati su identifikovali dugoročnu vezu između vojnih rashoda i ekonomskog rasta $u$ balkanskim zemljama na osnovu panel analize podataka. Takođe, empirijski nalazi su potvrdili da iskustvo šokova kod vojnih rashoda i ekonomskog rasta u jednoj od zemalja utiče na druge posmatrane zemlje. Rezultati su utvrdili jednosmernu kauzalnost od vojnih rashoda ka ekonomskom rastu u ovim zemljama, ali ne i obrnuto.

Ključne reči: vojni rashodi, ekonomski rast, balkanske zemlje, panel kointegraciona analiza. 


\section{Authors' biographies}

Branimir Kalaš, is an Assistant Professor at the Faculty of Economics in Subotica, University of Novi Sad. He graduated from the Faculty of Economics Subotica, University of Novi Sad in 2012 and earned his PhD degree in 2019 form the same institution. Also, he is a member of Serbian Fiscal SocietyNational Branch of International Fiscal Association (IFA). He has published several papers in the field of finance and taxes. His main fields are: public finance, taxes and tax systems in the European Union.

Vera Mirović is an Associate Professor at the Faculty of Economics in Subotica, University of Novi Sad. She graduated from the Faculty of Economics Subotica, University of Novi Sad and earned her PhD degree in 2013 from the same institution. She has published several papers in the field of finance. Her main field are investment banking and financial markets.

Nada Milenković, is an Assistant Professor at the Faculty of Economics in Subotica, University of Novi Sad. She graduated from the Faculty of Economics Subotica, University of Novi Sad and earned her PhD degree in 2016 from the same institution. She has published several papers in the field of finance. Her main fields are banking institutions and investment funds. 